\title{
Factors Affecting Budget Allocation to Education Sector (Case of Woredas in East Wollega Zone)
}

\author{
HASHIM TUNE SADO (MSc) \\ Wollega University, College of Business and Economics \\ Department of Accounting and Finance, P.O. Box: 395, Nekemte, Ethiopia.
}

\begin{abstract}
The study focuses on assessment of the factors affecting budget allocation to education sector, Survey of selected woredas in east wollega zone. Surveys of budget officials, interview with finance managers and documentary analysis used. The data was analyzed through us of SPS. The results reveal that, the factors affecting budget allocation to education sector are number of: beneficiaries, schools, Classrooms, staff by profession (teachers and administrative staff), and the other activities. But the variables are not supported by formula rather the budget allocated by budget official's judgment based on budget available and past performance report. Based on the finding, it is recommended that implementation of all factors in the allocation process practically, pool the factors together with formula, allow woredas to share experience to each other, provide training for staff periodically.
\end{abstract}

Keywords: Budget, Budget allocation, Factors, Woredas, education Sector

DOI: $10.7176 / \mathrm{RJFA} / 10-3-01$

\section{Introduction}

Modern budgeting systems were developed in the late 19th and early 20th centuries as a means of exerting legislative control over budget allocation decisions by the executive. This was achieved by dividing responsibility for and authority over the budget allocation process between institutions whose competencies and relations were defined in law, supplemented by exhaustive rules and procedures. A budget is a plan that tells us the amount and source of money to be allocated for the provision of a certain service among the priority lists.

Budgets are prepared at the Federal, regional, Woredas and urban administrations levels based on government policies and priorities. Among the most important current priorities are expansion of health services to citizens, creating access to potable water, construction of roads and education facilities. (MOFED, 2009)

In Oromia Before the state setting decentralization all administrative, financial and technical accountability were structured with in the sector vertically i.e. Sector Finance to Woreda Sector Office to Zonal Sector Department to Regional Sector Bureau. However, in the new system, all power of management has shifted to the woreda council, and sectoral bureaus retain authority in technical aspects only.

But what types of methods woreda can use and what are the main factors considered by woredas to allocate the budget to various sectors would questionable. An understanding of factors affecting budget allocation is essential and crucial to the allocation of the budget to sectors. One way to identify effective methods is, therefore, to investigate the factors that affect the budget allocation.

The proposed researches are trying to answer the following basic questions.

- What are the main factors affecting the budget allocation to education sector?

- Is there any recognized method (identified factors by woreda cabinet to allocate budget to education sector?

- What are the challenges faced by woredas in allocating budget to sectors?

The general objective of the study was to identify and examine factors that affect budget allocation to education sector by using descriptive data analysis.

\section{Specific Objective}

The specific objectives of this study were:

- To identify the factors affecting budget allocation to education sector.

- To asses existence of any recognized methods or identified factors by woreda cabinet to allocate budget to education sector.

- To identify the challenges faced by woredas in allocating budget to the sectors.

\section{Significance of the Study}

Very little studies made so far in Oromia regional state focusing on the budget allocation. As a result, this study can give an enormous contribution towards extended research in area of budget allocation. The study can give direction to the woredas finance and economic development office about the main factors considered in the budget allocation. 
In addition to this the investigator believes that this study may serve as a stepping stone for other researchers to undergo further research on the subject and will serve as reference material for those who are interested in the area.

\section{Scope of the Study}

As specified in the methodology section, the proposed research address one zone (East Wollega) and 6 woredas from the zone. The study considers the factors affecting budget allocation to Education sector. Thus, this study is not believed as holistic one in identifying factors that affect the budget allocation, some variables may be missed and some of these issues will be addressed in future work. In addition this study was delimited to only woredas and sectors budget officials of the selected woredas in East Wollega zone.

\section{Limitation of the Study}

Having the above significance, the study would subject to some limitations.

* There would be limitation of various research literatures specifically done on the area of budget allocation methods particularly of the Ethiopian case.

* The study did not represent all woredas in Oromia region because it is difficult to conclude the results based on six woredas for above 300 woredas and city administration in the region.

\section{Literature Review \\ Overview of Budget}

The term budget is used to mean a plan for financing an enterprise or government during a definite period, which is prepared and submitted by a responsible executive to a representative body whose approval and authorization are necessary before the plan may be, executed (Hyde, 1992). In short, modern budgeting system has three functions - allocation, stabilization and distribution function. Commonly government budget is prepared for a year, known as fiscal year or financial year. In Ethiopia the fiscal year is from July 7 of this year to July 6 of the coming year (Hamle 1 to Sene 30 in Ethiopian calendar) (Ramaswami, 2005).

\section{Budget Process}

The budget process is not just about collection of revenue and spending money to public bodies.

But it is also an ongoing complex procedure involving important policy statement, planning, and socioeconomic priorities, monitoring and reporting processes. It reflects government's view of socio-economic development of the country, the declaration of the fiscal, financial and economic development objectives of the country. The budget and its process is also important document in ensuring transparency, accountability and good governance.

The budget process shapes decision through the budget cycle. The budget cycle has four main stages: preparation of budget request, legislative approval, executive budget implementation, and summary of reporting on actual budget transaction (Bland and Rubin, 1997). Bland and Rubin have further substantiated the end product of each phase of budget cycle.

In the budget process, one of the principal issues is the degree of participation by interested parties. The chief executive bodies, policy-makers, budget analyst, department heads, citizens, and interested group representatives should all participate in the budget decision-making process (Bland and Rubin, 1997).

\section{Budget Planning at Woreda Level}

WOFED consolidates sector offices' work plans with budget proposal and submits to the Woreda Cabinet to be checked, scrutinized. WOFED makes adjustments on the basis of the comments from the Cabinet and submits the plan to the region via the zonal office, (where there are zones) which plays a facilitation and coordination role.

Approved budget notification, with some variations from the Woredas' proposed budget, normally reaches Woredas around mid July - Ethiopian calendar. Once the approved budget is received, WOFED makes final adjustments based on the approved ceiling and submits the same to the Woreda council to be approved and proclaimed. Budget utilization report is sent to the zonal ZOFED on monthly basis and quarterly, bi-annual and annual reports are also submitted to the region and the Woreda council. Closing of accounts is done annual basis by the sector offices' internal auditors who also regularly check and verify accounts. Each region allocates about two-thirds of its budget to Woredas and urban administrations. Woredas through their Inland Revenue offices are primarily responsible for collecting the region's revenue, mainly, in the form of taxes. These taxes are collected both at Woreda and Kebele level. The previous year's tax collection serves as a basis for BoFED to forecast the regions' own revenue (MOFED, 2009). 


\section{Budget Allocation Methods}

Any mechanism intended to transfer funds from one government to a set of others will entail three policy choices: (i) how to determine the total amount of budgets to be distributed; (ii) how to allocate that budget pool across all eligible sub-national governments; and (iii) if and how to restrict the way the transfer funds can be used. Appropriate design of a transfer system should consider each of these design features systematically. (Andrew Green, et al., 2000)

"The best formula is one that quantifies need with the minimum number of variables, since each variable adds time and expense of data collection as well as the number of calculations that must be made to implement the methods." (David Schappert, n.d.)

In many countries, for administrative reasons, budget allocation often is based on existing ministry structures and bureaucratic demand rather than on need (diderichsen, 2004).yet, in the interests of both horizontal and vertical equity, it is necessary that budget allocation be based more on need.

Budget allocation methods can help countries to reduce inequalities in access to woredas by systematically and objectively incorporating unit cost approach into allocation decisions. (BOFED, 2011)

\section{Empirical literature Education Sector}

According to BOFED (2011) the variables considered in: - Education sectors are School age population, Actual number of students enrolled, expected number of students to be served, Actual number of teachers, Number of schools, Number of classrooms, Unit Average construction cost per type of construction in the district, and Actual financial expenditure for salary and operation for the previous year.

Education sector major recurrent cost drivers are number of students, teachers' salary and operational expenses for teaching materials, stationary, maintenance, textbooks, general expenses, and etc. (BOFED, 2011).

The capital budget cost drivers are the amount of development infrastructures in education sectors with respect to the target population in the sector. The cost drivers for capital budget are relative in such a way that the deficit is calculated based on inter woredas comparison (ibid).

According to Iris Ben David-Hadar \& Adrian Ziderman, (2010) level of parent education, number of siblings, new immigrant status, national priority status and periphery location status, are the main factors affecting allocation methods.

\section{Research Approaches}

In order to achieve the objective of this study, the researcher used both quantitative and qualitative method of research approach with descriptive survey research design. Thus, the researcher examined major factors affecting budget allocations to education sectors with selected woredas.

\section{Sample and Sampling Techniques}

From the 21 zones found in Oromia region, one zone (East Wollega zone which comprise 17 woredas) and from the 17 woredas found in East wollega zone 6 woredas and one city administration(Guto Gida, Diga,Guto Wayu, Sire, Wayu Tuka, Sasiga and Nekemte town) are selected as centers of the study on the basis of convenience sampling method. In designing a sample, the researcher used different basic factors, such as availability of data, transportation service access, distance of woredas from the zone and others.

The total number of target population in the selected woredas is 140 woredas finance and budget officials and sector finance budget officials. From this population the researcher selected $70(50 \%)$ staffs by their position and relations to budget process (Budget and Disbursement team).

\section{Data Collection Tools}

Both primary and secondary data sources were used in the study. The primary data was collected from the woredas and sectors budget officials by using self-administered questionnaires and semi-structured interviews. Secondary data were gathered from document analysis of BOFED and WOFED, different related literatures such as books, journals, magazines, research reports, internet and others to support primary data.

\section{Methods of Data Analysis and Presentation}

To analyze and interpret the data obtained from respondent's descriptive statistics were used, with frequency, percentage by using SPSS. Furthermore, qualitative data gathered are used to supplement the data gathered through questionnaire were organized, summarized and interpreted in words qualitatively.

\section{Results and Discussion}

Description of Demographic Characteristics of Respondents

The selected sample size of this study was 70 employees for whom the questionnaires distributed in the six sample woredas and Nekemte city found in East wollega zone. Out of these, 60 copies filled and returned. The 
information obtained through interview and document analyses used as a complementary data for analysis. The characteristics of the subjects were their position and knowledge about budget.

Graph 4.1: Current Position of the Respondents

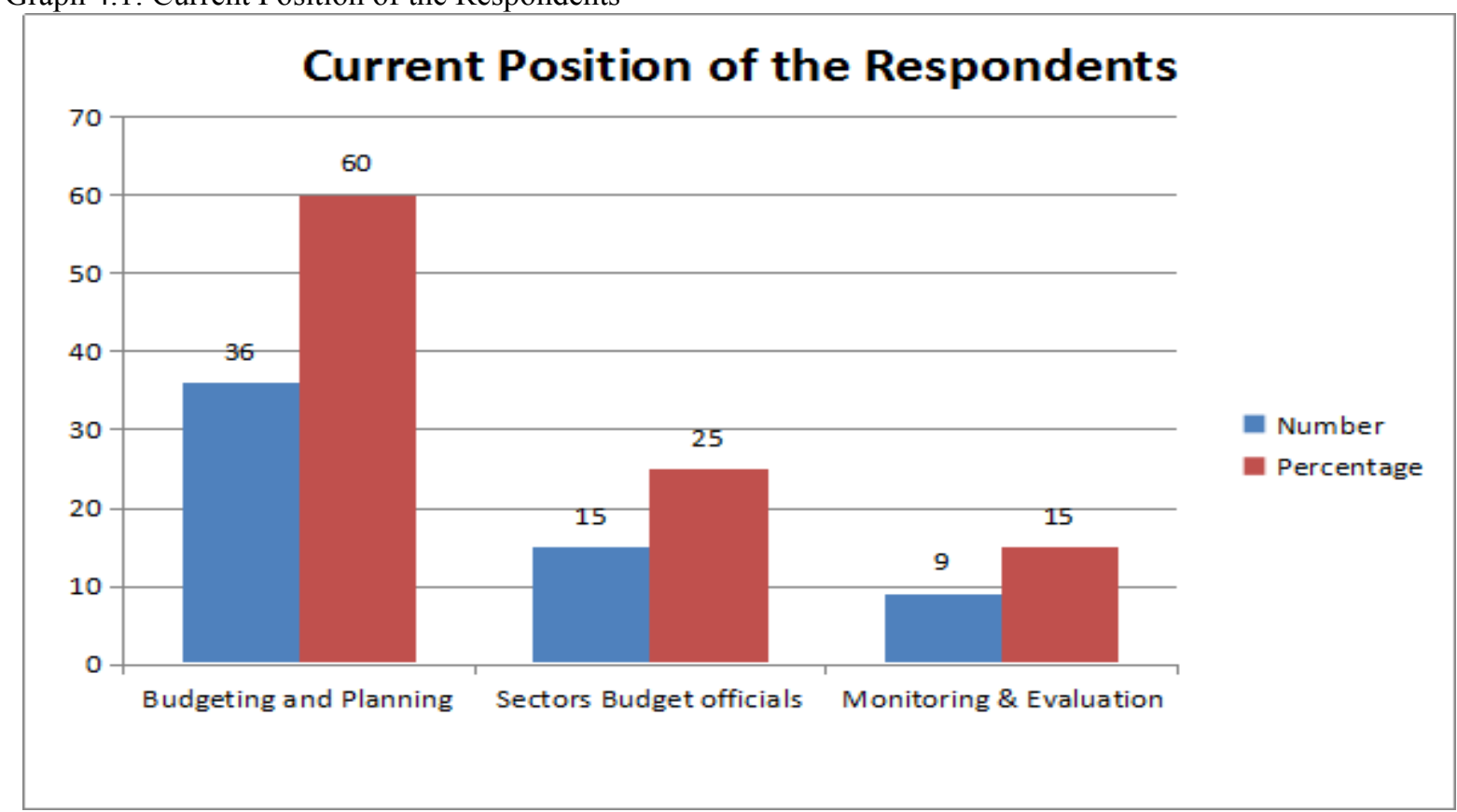

Source: Researcher Own Computation

As shown above, graph 4.4 tries to describe the respondents work experience or current position of employees in the office. Accordingly; $60 \%, 25 \%, 15 \%$ of the respondents have been serving as Budgeting \& Planning, Sectors budget officials and Monitoring \& Evaluation respectively. According to BPR (Business Process Reengineering) of the woredas, the budgeting and planning department has nine staffs, with a team of six Budgeting \& Planning and three Monitoring \& Evaluation, but no woreda has staff that meets the BPR.

Existence of Proclamation

Table 4.1: Officials Response on Budget Proclamation

\begin{tabular}{|l|l|l|}
\hline Items & № & Percentage \\
\hline Is there any proclamation regarding the budget allocation at woreda level? & 40 & 66.7 \\
a. Yes & 20 & 33.3 \\
b. No & 60 & 100 \\
\hline Total & & \\
\hline If your answer is "yes "for question No 1, do the factors affecting budget allocation & & \\
specified? & 10 & 25 \\
Yes & 30 & 75 \\
No & 40 & 100 \\
\hline Total &
\end{tabular}

Source: Survey results and Own Computation

* No.: represent total number of respondents

As indicated on table 4.1 item one, there is proclamation regarding budget allocation. Even though there were proclamations about budget allocation, the factors affecting budget allocation are not specified in the proclamation.

As the response from interviews regarding how woredas allocate budget to the sectors, the budget allocated to the sectors based on priority and activities to be performed in the sectors during the fiscal year. Generally, woredas have proclamation and regulations about budget allocation process which show the amount of budget allocated to each sectors but the factors affecting budget allocation are not listed specifically in the proclamation. This shows that the factors considered in the budget allocation process vary from woreda to woreda.

\section{Factors Affecting Budget Allocation to education sector}

In the budget allocation process at woreda level, woredas collect raw data from the sectors related to the main variables considered in the allocation for the period and made analysis on the data to see the reliability of the data before the allocation made and prioritize them based on its value on the development policy and strategy or 
the five year transformation plan of the country. The allocation criteria depend on the functions to be financed by the grants, and the complexity of services to be provided (The Republic of Uganda, 2003).

As per the employees response, factors considered in allocating budget to education sectors are number of: School age population, actual students enrolled, schools, expected students to be served, classrooms, actual teacher's, average construction cost per type of construction in the district, actual financial expenditure for salary and operation for the previous year(s).

As per Shoshani Committee (2001) budget allocation is the product of the number of students and the average differential (student) index for the school. The differential index is a per-student index calculated according to a needs-based formula. But as this study shows the allocation is not the product of students and average differential index for the school rather according to the criteria list (work plan, priority, poverty reduction and the others) by woredas cabinet. That means woredas does not allocate the budget as per the expenditure need of the sectors or not use need based approaches of budget allocation systems.

Besides, the opinion survey has been made to assess the factors considered in the budget allocation process at woreda level. The results of the study are presented here under:

\section{Response Scale}

\begin{tabular}{|l|l|l|l|l|}
\hline 1 & 2 & 3 & 4 & 5 \\
\hline Strongly Disagree & Disagree & Neutral & Agree & Strongly Agree \\
\hline
\end{tabular}

Table 4.2: Respondents View on Factors Considered in Allocating Budget

N: Total Number of Respondents

\begin{tabular}{|c|c|c|c|c|c|c|c|c|}
\hline \multirow[b]{2}{*}{ S.No } & \multirow[t]{2}{*}{ Factors criteria on budget allocation } & \multicolumn{5}{|c|}{ Response scale } & \multirow{2}{*}{ № } & \multirow[b]{2}{*}{ Mean } \\
\hline & & 1 & 2 & 3 & 4 & 5 & & \\
\hline 1 & $\begin{array}{l}\text { A development statue of the sector } \\
\text { affects the allocation }\end{array}$ & $\begin{array}{l}0 \\
0\end{array}$ & $\begin{array}{l}16 \\
26.7 \%\end{array}$ & $\begin{array}{l}10 \\
16.6 \%\end{array}$ & $\begin{array}{l}16 \\
26.7 \%\end{array}$ & $\begin{array}{l}18 \\
30 \%\end{array}$ & $\begin{array}{l}60 \\
100 \%\end{array}$ & 3.6 \\
\hline 2 & $\begin{array}{l}\text { Level of Poverty affects the allocation of } \\
\text { budget to sectors }\end{array}$ & $\begin{array}{l}4 \\
7.3 \%\end{array}$ & $\begin{array}{l}6 \\
10.9 \%\end{array}$ & $\begin{array}{l}5 \\
9.1 \%\end{array}$ & $\begin{array}{l}20 \\
36.4 \%\end{array}$ & $\begin{array}{l}25 \\
36.4 \%\end{array}$ & $\begin{array}{l}60 \\
100 \%\end{array}$ & 3.9 \\
\hline 3 & $\begin{array}{l}\text { Revenue generating capacity considered } \\
\text { in allocation }\end{array}$ & $\begin{array}{l}0 \\
0\end{array}$ & $\begin{array}{l}5 \\
9.1 \%\end{array}$ & $\begin{array}{l}6 \\
10.9 \%\end{array}$ & $\begin{array}{ll}32 \\
58.2 \%\end{array}$ & $\begin{array}{l}17 \\
21.8 \%\end{array}$ & $\begin{array}{l}60 \\
100 \%\end{array}$ & 4.0 \\
\hline 4 & $\begin{array}{l}\text { Levels of development infrastructures } \\
\text { with respect to the target population in } \\
\text { the sector are considered }\end{array}$ & 0 & 0 & 10 & $\begin{array}{l}36 \\
65.4 \% \\
\end{array}$ & 14 & $\begin{array}{l}60 \\
100 \% \\
\end{array}$ & 4.1 \\
\hline 5 & $\begin{array}{l}\text { Development policies, strategies and } \\
\text { priorities of the sectors are considered }\end{array}$ & 0 & 0 & $\begin{array}{l}6 \\
10.9 \%\end{array}$ & 25 & 29 & $\begin{array}{l}60 \\
100 \%\end{array}$ & 4.4 \\
\hline
\end{tabular}

*Totals and mean values may not agree due to rounding

Source: Researcher Own Computation

As it is indicated in table 4.2, development statue, Level of Poverty of the sector, Revenue generating capacity, Levels of development infrastructures and Development policies, strategies and priorities of the sectors affects the budget allocation with a mean value of 3.6, 3.9, 4, 4.1, and 4.4 respectively. As infrastructure need of the sectors meet the budget for capital project become decline and allocate more capital budget to sectors with infrastructures deficit. Sectors which are believed to reduce level of poverty share more budget than others. If the sectors have its own revenue sources, the revenue collected by the sectors considered in the budget allocation process that means the amount to be allocated for the sectors minimized by revenue generated. The sectors having infrastructure deficit in relation to target population can get higher capital budget to meet its infrastructure need. Development policies, strategies and priorities of the sectors are considered in the budget allocation process.

In line with all the above discussion regarding the factors considered in budget allocation; responses obtained through interview conducted with woredas managers revealed the same findings but they responded that all the factors are not proportionally considered because of budget deficit, and lack of appropriate formulas that summaries these all factors. Accordingly; they replied that by having all the above factors in mind budget allocation made based on the physical plan of the sector, their past year budget utilization, their role in poverty reduction, infrastructure need of the sectors, the transformation policy, strategy and priorities of the woredas.

\section{Recognized Methods or Identified Factors by Oromia Cabinet and the Methods Used}

As per the officials' response and document analysis of the selected woredas, regarding which methods used to allocate budget to the sectors, the incremental budget allocation method and block grant approaches are used.

The incremental budget allocation system used to calculate the amounts to be allocated for the sectors based 
on raw data from sectors. In this case actual financial expenditure for salary and operation for the previous year(s) used as a base and performed the adjustments for fiscal year based on available data of the sector during the year and distributing the budget to the sectors using block grant approaches. That means the block grant amounts which total the recurrent and capital budget are allocated to the sectors and the authority to share the budget as recurrent and capital are that of the sectors. From the above discussions, it is possible to conclude that budget allocation is not made as per the expenditure need of the sectors.

Regarding the parties involved in designing budget allocation methods, the question results show that, the mandate to develop budget allocation methods at woreda level is that of WOFED and woreda cabinet.

The principals were asked regarding variation of budget allocation methods from woreda to woreda. Accordingly, they replied that all woredas set their own methods to allocate budget they have to all sectors based on the fiscal year work plan. Hence, in situation without any uniform methods for all woredas there is variation in the budget allocation system from woreda to woreda. From this, the researcher concludes that the methods used to allocate budget to sectors and the factors to be considered in budget allocation process may vary from woreda to woreda because each woreda set their own budget allocation methods based on different criteria. This indicates that there are no uniform factors and methods for all woredas which is set and recognized at regional level or zonal level.

As per respondents response, regarding responsible bodies for budget allocation to sectors and purpose of budget allocation; woreda finance office is responsible to allocate budget for sectors to fulfill expenditure need of the sectors. And also Budget is allocated to sectors to enhance rural development, to enable sectors to fulfill their expenditure responsibility and to fund construction of infrastructure respectively. The interview results also support the above idea but both to enhance rural development and for construction of infrastructures are part of fulfilling the expenditure responsibility of the sectors. That means woredas allocate the budget to fulfill the expenditure responsibility of the sectors.

Respondents were asked to give their response on who monitor the utilization of the budget, accordingly the largest number of respondents responded that Woreda finance and economic development and BoFED monitor the utilization of budget. The primary authority to monitor utilization of budget by the sectors is that of the woredas which is monitored by BoFED through ZOFED.

\section{Respondents View on Budget Allocation}

Table 4.4: Respondents View on Base of Allocation and Fairness

\begin{tabular}{|c|c|c|c|c|c|c|c|c|}
\hline \multirow[b]{2}{*}{ S.No. } & \multirow{2}{*}{$\begin{array}{l}\begin{array}{l}\text { Factors criteria on budget } \\
\text { allocation }\end{array} \\
\end{array}$} & \multicolumn{5}{|c|}{ Response scale } & \multirow[b]{2}{*}{ No } & \multirow[b]{2}{*}{ Mean } \\
\hline & & 1 & 2 & 3 & 4 & 5 & & \\
\hline 1 & $\begin{array}{l}\text { Budget allocations to sectors are } \\
\text { fair and equitable. }\end{array}$ & $\begin{array}{l}5 \\
8.3 \% \\
\end{array}$ & $\begin{array}{l}42 \\
70 \%\end{array}$ & $\begin{array}{l}0 \\
0\end{array}$ & $\begin{array}{l}13 \\
21.7 \%\end{array}$ & $\begin{array}{l}0 \\
0\end{array}$ & $\begin{array}{l}60 \\
100 \%\end{array}$ & 2.4 \\
\hline 2 & $\begin{array}{l}\text { Budget allocation made based on } \\
\text { need }\end{array}$ & $\begin{array}{l}5 \\
8.3 \%\end{array}$ & $\begin{array}{l}42 \\
70 \%\end{array}$ & $\begin{array}{l}0 \\
0\end{array}$ & $\begin{array}{ll}13 \\
21.7 \%\end{array}$ & $\begin{array}{l}0 \\
0\end{array}$ & $\begin{array}{l}60 \\
100 \%\end{array}$ & 2.4 \\
\hline 3 & $\begin{array}{l}\text { Budget allocation made based on } \\
\text { population size }\end{array}$ & $\begin{array}{l}14 \\
23.3 \%\end{array}$ & $\begin{array}{l}24 \\
40 \%\end{array}$ & $\begin{array}{l}0 \\
0\end{array}$ & $\begin{array}{l}16 \\
26.7 \%\end{array}$ & $\begin{array}{l}6 \\
10 \%\end{array}$ & $\begin{array}{l}60 \\
100 \%\end{array}$ & 2.6 \\
\hline
\end{tabular}

Source: Researcher Own Computation

Table 4.4 depicts respondents view on base of budget allocation and fairness in the woredas. As indicated on the above table item 1 the mean value of 2.4 indicates that budget allocations systems at the woreda level are not fair and equitable because the budget allocated based on budget officials judgment; it is not supported by appropriate formulas.

With regard to item 2, budget allocation made based on need of the sectors, the Mean value of 2.4 indicates that Budget allocation is not made based on need of the sectors. Also as the results of interview held with budget officials shows budget allocation to the sectors are not need based because of budget deficit that means the budget of woredas does not fulfill the need of all sectors. Budget allocation to sectors is not based on their expenditure need rather based on the criteria set by woredas cabinet and WOFED.

Regarding item 3 of table 4.4, respondents were asked whether Budget allocation to sectors is made based on population size; mean value of 2.6 indicate that Budget allocation not made based on population size. As the results from interview and secondary data analysis show, budget allocation for each sectors are made based on population which are beneficial from the service provided by the sectors, that means not according to the total population of the woredas. Generally, from the above table 4.4 the researcher concludes that budget allocations to the sectors made based on the priority of the sectors and criteria set by woredas cabinet rather than need of the sectors.

\section{Challenges Faced By Woredas in the Budget Allocation Process}

As the Interview held with woredas finance manager result shows some challenges and constraints that were experienced while utilizing the budget allocation methods are presented as follows: 
For the interview question why woredas fail to apply need based approaches of budget allocation majority of the interviewee replied that supreme power of the woredas cabinet that force woreda finance and economic development to perform the allocation according to their interest, lack of skilled manpower at woreda level to allocate budget as per need based approaches, insufficient budget amount or budget deficit, are the main challenges. From this budget allocation made without recognizing the service delivered, inability to support budget for the sectors according to their calculated need, capital budget is allocated irrespective of the recurrent capacity, budget is skewed to salary leaving little budget for the operational because of budget deficit. And the methods used currently by woredas in the allocation process does not explain the relationship between the weight of policy indicators and expenditure needs and does not explicitly show the relationship between financial performance and government policies, goals and objectives. And also lack of quality data, lack of commitment and attention by sectors in providing true data, and the like are the main challenges faced by woredas in the budget allocation process.

\section{Conclusion}

From the view point of the findings obtained, the researcher has made the following concluding remarks.

At woreda level there are budget proclamations regarding budget allocation but even though there were proclamation about budget allocation, the factors affecting budget allocation is not specified. The factors affecting budget allocation for education sector are; number of: students, schools, classrooms, teachers, and others. But; these all factors do not pooled together to compute the amount allocated to the sector for the lack of appropriate formulas. This shows that budget allocation system at woreda level is subjective, which is made as of the woredas cabinet judgments. Each woredas allocate the budget to their sectors based on the mechanisms set by woredas cabinet therefore, the mechanism in which woredas allocate budget may vary from woreda to woreda.

Budget allocation to the sectors is made to fulfill expenditure responsibility of the sectors by using Incremental budget allocation method and block grant approaches of budget allocation which is not need based.

Supreme power of the woredas cabinet, lack of skilled manpower at woreda level regarding budget allocation, budget deficit, lack of networking woredas for experience sharing, Lack of quality data from the sectors, Lack of commitment and attention by sectors and others are the main challenges faced by woredas in allocating budget to the sectors.

\section{Recommendations}

Based on the major funding of this study, the researcher forwarded the following recommendation:

It is better to provide training to improve the capacity of budget officers and data providers and create awareness about the factors affecting budget allocation to all concerned parties. The woredas should be performing budget allocation by using formula which considers all the identified factors in this study. Woredas should be networked through zone to each other to share experience on the budget allocation process. Budget allocation should be made based on the expenditure need of the sectors rather than subjective weight of the woredas cabinet and budget officers.

Generally, the researcher recommends that; further research should be done to identify the best formulas which meet the expenditure need of the sectors also on utilization of budget by the sectors.

\section{Bibliography}

Andrew Green, et al., 2000. Policy and Practice, Budget allocation and budgetary mechanisms for decentralized health systems: experiences from Balochistan, Pakistan. Bulletin of the World Health Organization, 78 (8)

Bland, R.L and Rubin, I.S. (1997). Budgeting, A Guide for Local Government, Printed and Binding by: United Book Press,Inc., Baltimor,Maryland

BOFED., 2011. The Regional Government of Oromia Bureau of Finance and Economic Development. An Overview of the Experience of Oromia in Woredas/Town Administrations Block Grant Allocation Methods (Unit Cost Approach)

David Schappert, sited in Tuten, Jane H. and Beverly Jones, 1995. Allocation Methodss in Academic Libraries, American Library Association. Washington: World Bank Institute.

Diderichsen, F. (2004). Budget Allocation for Health Equity: Issues and Methods. Washington, DC, World Bank: 1-23.

MoFED (2009). Ethiopia: laypersons guide to the public budget process at regional and woreda level. Ministry of Finance and Economic Development. Addis Ababa

Proclamation No. 159 /2002, Budget Proclamation for Oromia Regional State Services, Budget Proclamation of 2010/2011.

Shoshani Committee., 2001. Report of the Committee appointed for Examining the Budgetary Allocation Mechanism's. Jerusalem, Israel: Ministry of Education. 